\title{
ANALISIS RANTAI PASOK DAN STRATEGI PENGEMBANGAN SUSU KAMBING PASTEURISASI DI GOATZILLA FARM \& CAFÉ
}

\author{
Nurlita Lailia, M. Rondhi'1), dan Djoko Soejono \\ Program Studi Agribisnis Fakultas Pertanian Universitas Jember \\ Jl. Kalimantan No. 37 Jember, Jawa Timur, Indonesia \\ 1)e-mail: rondhi.faperta@unej.ac.id
}

(Diterima 2 Januari 2020 / Disetujui 3 Februari 2020)

\begin{abstract}
Goatzilla Farm \& Cafe is agroindustry in Lumajang which processes goat milk into various products and has several business units that related to enduro goat farms. The main product of Goatzilla Farm and Cafe is pasteurized goat milk. the scale of goat milk pasteurized production is still small category because the labour used is labour in the family, the supply of fresh goat milk is uncertain, and product marketing is still limited due to BPOM's permit constraints. Therefore, it is necessary to make efforts to develop pasteurized milk products at Goatzilla Farm \& Cafe. This research aims to determine supply chain, valueadded, and development strategy of goat pasteurized milk at Goatzilla Farm \& Cafe. The location of the research was determined by the purposive method. The research method used descriptive and analytic methods. The result of the research showed that the links involved in the supply chain of pasteurized goat milk are Goatzilla farm units, partner farmers, collectors, the processing unit of Senduro Goatmilk Indonesia, Goatzilla Farm \& Cafe, Senduro Goatmilk Indonesia outlet, and consumers. The processing of fresh goat milk into pasteurized goat milk provides positive value-added and can be classified as a medium category. The recommended strategy for the development of pasteurized goat milk based on the FKK value of the highest driving and inhibiting factors is to form a cooperative business entity engaged in agribusiness of Senduro goat milk.
\end{abstract}

Keywords: force field analysis, senduro goatmilk, supply chain, value added

\begin{abstract}
ABSTRAK
Goatzilla Farm \& Cafe merupakan agroindustri di Kabupaten Lumajang yang mengolah susu kambing menjadi berbagai produk serta memiliki beberapa unit usaha terkait peternakan kambing senduro. Produk utama dari Goatzilla Farm \& Cafe adalah susu kambing pasteurisasi. Skala produksi susu kambing pasteurisasi masih tergolong kecil dikarenakan tenaga kerja yang digunakan merupakan tenaga kerja dalam keluarga, pasokan susu kambing segar yang tidak menentu, dan pemasaran produk masih terbatas karena tekendala izin edar BPOM. Oleh karena itu, perlu adanya upaya agar produk susu pasteurisasi di Goatzilla Farm \& Cafe dapat semakin berkembang. Penelitian ini bertujuan mengetahui aliran rantai pasok, nilai tambah, dan strategi pengembangan susu kambing pasteurisasi di Goatzilla Farm \& Cafe. Lokasi penelitian ditentukan secara sengaja. Metode penelitian menggunakan metode deskriptif dan analitik. Berdasarkan analisis yang dilakukan, diketahui bahwa mata rantai yang terlibat dalam rantai pasok susu kambing pasteurisasi adalah unit peternakan Goatzilla, peternak mitra, pengepul, unit pengolahan Senduro Goatmilk Indonesia, Goatzilla Farm \& Cafe, outlet Senduro Goatmilk Indonesia, dan konsumen. Pengolahan susu kambing segar hingga menjadi susu kambing pasteurisasi memberikan nilai tambah yang positif dan tergolong kategori sedang. Rekomendasi strategi pengembangan susu kambing pasteurisasi adalah membentuk badan usaha koperasi yang bergerak dalam bidang agribisnis susu kambing senduro.
\end{abstract}

Kata Kunci: analisis medan kekuatan, nilai tambah, rantai pasok, susu kambing senduro

\section{PENDAHULUAN}

Kambing peranakan etawa merupakan salah satu jenis kambing penghasil susu yang banyak ditemui di Indonesia (Pamungkas et al.,
2009). Populasi ternak kambing peranakan etawa di Indonesia termasuk terbesar di dunia, dan seperti diketahui bahwa kambing peranakan etawa adalah penghasil susu yang sangat potensial (Utami, 2016). Susu kambing saat ini 
semakin populer karena kandungan zat gizinya lebih tinggi daripada susu sapi, serta diyakini dapat digunakan sebagai obat untuk beberapa jenis penyakit. Dengan demikian, permintaan susu kambing ini akan selalu ada dan semakin meningkat (Saparinto, 2011).

Kambing Senduro merupakan salah satu jenis kambing peranakan etawa yang berasal dari persilangan antara kambing jamnapari asal India dengan kambing menggolo yang merupakan kambing lokal Lumajang. Kambing Senduro menjadi komoditas unggulan di Kabupaten Lumajang, baik ternak maupun produk turunannya. Kambing peranakan etawa di Kabupaten Lumajang atau yang dikenal dengan kambing Senduro memiliki karakteristik khusus dibanding kambing peranakan etawa di wilayah lainnya, sehingga ditetapkan sebagai ternak lokal berdasarkan Keputusan Menteri Pertanian RI Nomor: 1055/Kpts/SR.120/10/ 2014, di mana dalam keputusan tersebut ditetapkan bahwa kambing Senduro merupakan kekayaan sumberdaya genetik ternak lokal Indonesia yang harus dilindungi dan dilestarikan. Karakteristik dari kambing Senduro diantaranya warna bulu dominan putih, telinga panjang menggantung ke bawah dan terpilin, serta umumnya tidak bertanduk. Cita rasa susu yang lebih gurih dibanding susu kambing jenis lain sehingga diperkirakan jika kandungan mineral susu kambing Senduro lebih tinggi dari susu sejenis (Siswanto, 2014).

Sentral peternakan kambing Senduro di Lumajang adalah di sekitar lereng Pegunungan Semeru, tepatnya di Kecamatan Senduro dan Kecamatan Pasrujambe. Walaupun kambing Senduro berpotensi sebagai penghasil susu, hanya sebagian peternak saja yang fokus pada pemerahan susu, sementara sebagian lainnya adalah untuk diambil dagingnya dan pembibitan. Padahal, susu kambing dapat memiliki nilai jual yang tinggi dan dapat meningkatkan pendapatan peternak apabila diolah dengan baik.

Goatzilla Farm \& Cafe merupakan agroindustri di Kabupaten Lumajang yang mengolah susu kambing menjadi berbagai produk dan didalamnya terdapat beberapa unit usaha terkait dengan peternakan kambing senduro. Produk utama dari Goatzilla Farm \& Cafe adalah susu pasteurisasi, yaitu susu kambing segar yang dipanaskan pada suhu tertentu di bawah titik didih susu sehingga memiliki daya simpan lebih lama tanpa merubah bentuk dan rasanya (Wanniatie dan Hanum, 2015). Pemasaran susu pasteurisasi di Goatzilla Farm \& Cafe masih terbatas di wilayah Lumajang, yaitu pada outletoutlet tertentu. Sementara untuk luar daerah Lumajang, pembelian produk harus melalui pemesanan terlebih dahulu. Terbatasnya pemasaran produk olahan Goatzilla Farm \& Cafe adalah karena belum adanya izin BPOM sehingga produk tidak dapat dijual secara bebas, di mana salah satu syarat untuk memperoleh izin dari BPOM adalah harus memiliki pabrik. Oleh karena itu, perlu adanya upaya agar Goatzilla Farm \& Cafe dapat bertahan dan semakin berkembang agar skala produksinya semakin meningkat dan dikenal oleh masyarakat luas.

Proses pasteurisasi susu kambing segar di Goatzilla Farm \& Cafe hingga susu siap dikonsumsi dan diterima oleh konsumen membentuk suatu rantai pasokan yang melibatkan beberapa mata rantai, mulai dari supplier hingga konsumen akhir. Mata rantai yang terlibat dalam rantai pasok susu pasteurisasi di Goatzilla Farm \& Cafe perlu diidentifikasi guna mengetahui keadaan ataupun kendala dari sudut pandang dari masingmasing mata rantai, sehingga dari identifikasi tersebut diharapkan kendala dari setiap mata rantai dapat teratasi. Aliran rantai pasok susu kambing segar hingga menjadi susu pasteurisasi tentunya memberikan perubahan nilai produk karena adanya proses pengolahan dari susu kambing segar hingga menjadi susu pasteurisasi, sehingga memberikan nilai tambah. Proses pemberian nilai tambah tersebut dilakukan oleh unit pengolahan Senduro Goatmilk Indonesia yang merupakan bagian dari Goatzilla Farm dan Cafe.

Beberapa penelitian terdahulu terkait rantai pasok produk susu telah banyak dilakukan. Menurut Azhim et al. (2014) dalam penelitiannya yang berjudul Strategi Pengembangan Industri Pengolahan Susu Sapi di Kabupaten Sinjai Sulawesi Selatan, rantai pasok pengusahaan susu sapi di Kabupaten Sinjai melibatkan pemasok saprodi, inseminator, peternak sapi perah, kelompok ternak, koperasi susu, Disnakeswan, 
distributor, serta pedagang lokal. Menurut Isnia et al. (2017) dalam penelitiannya yang berjudul Analisis Manajemen Rantai Pasok Susu Sapi Perah pada Koperasi Peternak Galur Murni di Kecamatan Sumberbaru Kabupaten Jember, manajemen rantai pasok susu sapi perah di Koperasi Peternak Galur Murni Kecamatan Sumberbaru Kabupaten Jember memiliki tiga aliran yaitu aliran produk, aliran keuangan dan aliran informasi. Aliran produk dalam rantai pasokan susu sapi perah di Koperasi Peternak Galur Murni dapat dibedakan menjadi dua macam aliran, yaitu aliran produk berupa susu sapi (segar) dan aliran olahan susu sapi. Aliran keuangan dalam rantai pasok susu sapi perah mengalir dari konsumen akhir sampai ke peternak. Aliran ini dibedakan menjadi enam macam aliran dengan sistem pembayaran tunai, kredit, berkala dan konsinyasi. Aliran informasi dalam rantai pasokan susu sapi perah di Koperasi Peternak Galur Murni terbagi menjadi dua macam aliran, yaitu aliran informasi secara horizontal dan aliran informasi secara vertikal terkait stok susu dan produk olahan yang tersedia, jumlah permintaan produk, serta informasi harga susu dan produk olahan. Menurut Liputra et al. (2015) dalam penelitiannya yang berjudul Pemetaan Entitas dan Aliran pada Jaringan Sistem Rantai Pasok Produk Susu (Studi Kasus di PT. Frisian Flag Indonesia), aliran informasi di dalam entitas rantai pasok penghasil produk Susu Bendera meliputi informasi permintaan terhadap produk jadi Susu Bendera, permintaan bahan baku dari PT. Foremost Indonesia (PT. FI) dan PT. Frisian Vlag Indonesia (PT. FVI) ke supplier, dan informasi terkait keterlambatan distributor dalam pembayaran, serta penagihan terhadap distributor yang belum melakukan pembayaran produk Susu Bendera. Aliran produk pada rantai pasok Susu Bendera adalah aliran bahan baku dari supplier ke PT. FI dan PT. FVI dan aliran produk jadi dari PT. Tesori Mulia ke berbagai pihak distributor hingga sampai ke tangan konsumen. Aliran pembayaran terdiri atas aliran pembayaran bahan baku dari PT. FFI ke supplier, pembayaran produk jadi Susu Bendera dari berbagai pihak distributor ke PT. FFI maupun dari pihak retailer ke pihak distributor tersebut. Menurut Putri (2015) dalam penelitian- nya yang berjudul Analisis Risiko Rantai Pasok Susu Pasteurisasi dengan Fuzzy Failure Mode and Effect Analysis, mekanisme rantai pasok susu pasteurisasi pada PT. Greenfields Indonesia (PT. GI) dimulai pada tahap peternakan, pemrosesan, penyimpanan dan penggudangan, transportasi dan distribusi. Terdapat tiga macam aliran dalam rantai pasok susu pasteurisasi di PT. GI, yaitu aliran barang, aliran finansial, dan aliran informasi. Aliran barang mengalir dari hilir ke hulu, yaitu mulai dari (1) pemasok yang terdiri atas unit peternakan dan KUD/MCC, (2) unit pemrosesan yang terdiri atas proses produksi dan warehouse atau gudang penyimpanan sementara sebelum susu dikirim ke distributor dan customer, (3) distributor, (4) retailer, hingga ke (5) konsumen akhir, sedangkan aliran finansial susu pasteurisasi di PT. GI mengalir dari hilir ke hulu. Aliran informasi di PT. GI terjadi pada semua pihak dalam rantai pasok, umumnya terkait dengan permintaan dan ketersediaan produk.

Akan tetapi, penelitian terkait rantai pasok susu kambing pasteurisasi di Goatzilla Farm \& Cafe masih belum pernah dilakukan. Identifikasi mata rantai yang terlibat dalam rantai pasok serta nilai tambah susu pasteurisasi di Goatzilla Farm \& Cafe dapat menjadi suatu gambaran dalam pembentukan rekomendasi strategi pengembangan susu kambing pasteurisasi di Goatzilla Farm \& Cafe. Hal tersebut melatarbelakangi dilaksanakannya penelitian ini, di mana tujuan dari penelitian adalah mengetahui (1) aliran rantai pasok susu kambing pasteurisasi;

(2) nilai tambah susu kambing pasteurisasi; dan

(3) strategi pengembangan susu kambing pasteurisasi di Goatzilla Farm \& Cafe.

\section{METODE}

Lokasi penelitian ditentukan secara sengaja, yaitu di Goatzilla Farm \& Cafe Kecamatan Senduro Kabupaten Lumajang dengan pertimbangan (1) Goatzilla Farm \& Cafe mengolah susu kambing senduro menjadi berbagai produk dan telah diakui oleh pemerintah setempat; (2) produk olahan susu di Goatzilla Farm \& Cafe telah memiliki merek dagang berupa Daimeru yang terdaftar di Direktorat Jenderal Kekayaan 
Intelektual (DJKI) Kemenkumham RI; dan (3) pemasaran susu pasteurisasi di Goatzilla Farm \& Cafe masih terbatas karena terhambat perizinan BPOM. Metode penelitian yang digunakan adalah metode deskriptif dan metode analitik. Metode deskriptif adalah metode untuk menggambarkan situasi atau kejadian sehingga peneliti dapat memberikan gambaran mengenai fenomenafenomena dan juga menerangkan hubungannya, membuat prediksi, serta menyimpulkan makna atas persoalan yang dibahas (Sumodiningrat, 2007). Metode penelitian analitik merupakan metode untuk menguji hipotesis dan mengadakan interpretasi yang lebih dalam (Nazir, 1999). Metode analitik digunakan untuk mengetahui nilai tambah yang diperoleh dari pengolahan susu kambing segar menjadi susu pasteurisasi serta menentukan faktor kunci keberhasilan (FKK) faktor pendorong dan penghambat pada pengembangan susu pasteurisasi, sedangkan metode deskriptif digunakan untuk mendeskripsikan rantai pasok serta strategi pengembangan susu pasteurisasi di Goatzilla Farm \& Cafe.

Responden atau mata rantai yang terlibat dalam rantai pasok susu kambing pasteurisasi dari Goatzilla Farm \& Cafe ditentukan dengan menggunakan metode snowball sampling yang bergerak dua arah berdasarkan informasi yang diperoleh dari pemilik agroindustri terkait dengan supllier dan lembaga pemasaran yang terlibat. Responden terkait dengan analisis nilai tambah dan strategi pengembangan susu pasteurisasi di Goatzilla Farm \& Cafe ditentukan dengan metode purposive sampling. Responden terkait nilai tambah susu kambing pasteurisasi adalah pemilik Goatzilla Farm \& Cafe, sedangkan responden untuk strategi pengembangan susu kambing pasteurisasi adalah expert dari Dinas Perindustrian dan Perdagangan (Disperindag), Dinas Pertanian dan Peternakan, serta Dinas Koperasi, Usaha Kecil dan Menengah Kabupaten Lumajang.

Pengumpulan data dilakukan melalui observasi, interview, serta studi dokumentasi. Observasi dan interview dilakukan dengan wawancara langsung kepada pemilik dan pengelola agroindustri, supplier dan distributor produk, serta pihak-pihak yang terkait dengan pengembangan agroindustri dengan cara melakukan peninjauan langsung pada obyek penelitian dan menggunakan kuisioner yang telah dipersiapkan. Studi dokumentasi dilakukan untuk melengkapi data terkait penelitian yang diperoleh dari instansi atau kantor dinas yang terkait dengan penelitian ini serta berbagai literatur dan sumber-sumber terkait lainnya.

Identifikasi rantai pasok susu kambing pasteurisasi dilakukan secara deskriptif sehingga diperoleh gambaran terkait aliran produk, aliran biaya, dan aliran informasi susu kambing pasteurisasi di Goatzilla Farm \& Cafe. Analisis deskriptif mengubah kumpulan data mentah menjadi bentuk yang mudah dipahami dan dalam bentuk informasi menjadi bentuk yang lebih ringkas. Pendeskripsian dari hasil observasi merupakan ciri khas dari analisis deskriptif (Wibisono dalam Salsabila et al., 2014).

Nilai tambah pengolahan susu kambing segar menjadi susu pasteurisasi diselesaikan dengan menggunakan metode Hayami. Analisis nilai tambah melalui metode Hayami dapat menghasilkan beberapa informasi penting, antara lain (1) perkiraan nilai tambah; (2) rasio nilai tambah terhadap produk jadi (\%); (3) imbalan jasa tenaga kerja; (4) bagian tenaga kerja (\%); dan (5) keuntungan yang diterima perusahaan (Ruauw et al., 2012). Adapun kriteria pengambilan keputusan nilai tambah menurut Hayami et al. (1987) sebagai berikut:

1. $\mathrm{VA}>0$, artinya proses pengolahan susu kambing menjadi susu pasteurisasi memberikan nilai tambah.

2. VA $\leq 0$, artinya proses pengolahan susu kambing menjadi susu pasteurisasi belum mampu memberikan nilai tambah.

Menurut Hubeis (1997), terdapat tiga kiteria indikator rasio nilai tambah sebagai berikut:

1. Jika rasio nilai tambah $<15 \%$, maka nilai tambah produk tergolong rendah

2. Jika rasio nilai tambah $15 \%$ - $40 \%$, maka nilai tambah produk tergolong sedang

3. Jika rasio nilai tambah $>40 \%$, maka nilai tambah produk tinggi

Strategi pengembangan susu pasteurisasi di Goatzilla Farm \& Cafe diselesaikan dengan menggunakan analisis medan kekuatan (Force 
Field Analysis), di mana FFA merupakan suatu alat analisis yang digunakan dalam merencanakan perubahan berdasarkan adanya faktor pendorong dan penghambat yang ada (Hanafie et al., 2016). Menurut Sianipar dan Entang dalam Hariyati (2014), tahap-tahap dalam analisis FFA adalah sebagai berikut:

1. Identifikasi Faktor Pendorong dan Penghambat

Perumusan faktor pendorong dan penghambat diawali dengan wawancara dengan informan kunci dan survei daerah penelitian. Selanjutnya dirumuskan faktor pendorong dan penghambat awal yang kemudian digunakan untuk brainstorming dengan responden penelitian. Untuk menentukan faktor keberhasilan sebagai faktor-faktor strategis atau faktor kunci keberhasilan, maka perlu dilakukan penilaian terhadap setiap faktor yang teridentifikasi, yaitu (1) urgensi atau bobot faktor dalam mencapai tujuan; (2) dukungan atau kontribusi faktor dalam mencapai tujuan; dan (3) keterkaitan antar faktor dalam mencapai tujuan. Penilaian terhadap faktorfaktor dilakukan secara kualitatif yang dikuantitatifkan melalui metode skala Likert dengan rentang nilai 1 sampai dengan 5 .

2. Penilaian Faktor Pendorong dan Penghambat

a. Penentuan Nilai Urgensi (NU) dan Bobot Faktor (BF).

$$
\mathrm{BF}=\frac{\mathrm{NU}}{\mathrm{TNU}} \times 100 \%
$$

b. Penentuan Nilai Dukungan (ND) dan Nilai Bobot Dukung (NBD).

$$
\mathrm{NBD}=\mathrm{ND} \times \mathrm{BF}
$$

c. Penentuan Nilai Keterkaitan (NK)

d. Penentuan TNK (Total Nilai Keterkaitan)

e. Nilai Rata-rata Keterkaitan (NRK)

$$
\mathrm{NRK}=\frac{\mathrm{TNK}}{\sum \mathrm{N}-1}
$$

f. Nilai Bobot Keterkaitan (NBK) $\mathrm{NBK}=\mathrm{NRK} \times \mathrm{BF}$

g. Penentuan Total Nilai Bobot Faktor (TNB)

$$
\mathrm{TNB}=\mathrm{NBD}+\mathrm{NBK}
$$

3. Penentuan FKK dan Diagram Medan Kekuatan

a. Cara untuk menentukan FKK antara lain seperti berkut:

1. Dipilih berdasarkan TNB terbesar

2. Apabila TNB sama pilih BF terbesar

3. Apabila BF sama pilih NBD terbesar
4. Apabila NBD sama maka pilih NBK terbesar

5. Apabika NBK sama pilih bedasarkan pengalaman dan pertimbangan rasionalitas.

b. Diagram Medan Kekuatan

Apabila jumlah TNB faktor pendorong lebih besar dari pada TNB faktor penghambat, berarti sistem memiliki keunggulan dalam pengembangannya, dengan kata lain prospektif untuk dikembangkan. Sebaliknya bila jumlah TNB faktor pendorong lebih kecil dibandingkan TNB faktor penghambat maka, sistem tidak lagi prospektif untuk dikembangkan.

4. Penyusunan Rekomendasi Kebijakan

Rekomendasi strategi pengembangan disesuaikan dengan kenyataan yang ada di lapang. Susu pasteurisasi di Goatzilla Farm \& Cafe dapat dikembangkan dengan memfokuskan pada faktor pendorong yang dominan, serta meminimalisir atau menghilangkan faktor penghambat yang ada.

\section{HASIL DAN PEMBAHASAN}

\section{ALIRAN RANTAI PASOK SUSU KAMBING PASTEURISASI DI GOATZILLA FARM \& CAFE}

Rantai pasok merupakan segala aktivitas yang terintegrasi termasuk didalamnya juga aliran informasi yang berkaitan dengan tiga aspek, yaitu sumber, proses produksi, dan proses penghantaran produk (Furqon, 2014). Pola aliran dalam rantai pasok susu kambing pasteurisasi di Goatzilla Farm \& Cafe dapat dikatakan masih tergolong sederhana karena tidak banyak melibatkan mata rantai di dalamnya, khususnya dalam pemasaran produk. Mata rantai yang terlibat diantaranya pemasok. unit pengolahan, distributor, dan konsumen. Adapun aliran rantai pasok susu kambing pasteurisasi di Goatzilla Farm \& Cafe dapat dilihat pada Gambar 1.

Aliran produk merupakan perpindahan produk dari hulu (upstream) ke hilir (downstream). Terdapat dua macam bentuk aliran produk dalam rantai pasok susu pasteurisasi, yaitu aliran berupa susu kambing segar dan aliran berupa olahan susu kambing, yaitu susu pasteurisasi. Aliran produk susu kambing segar 


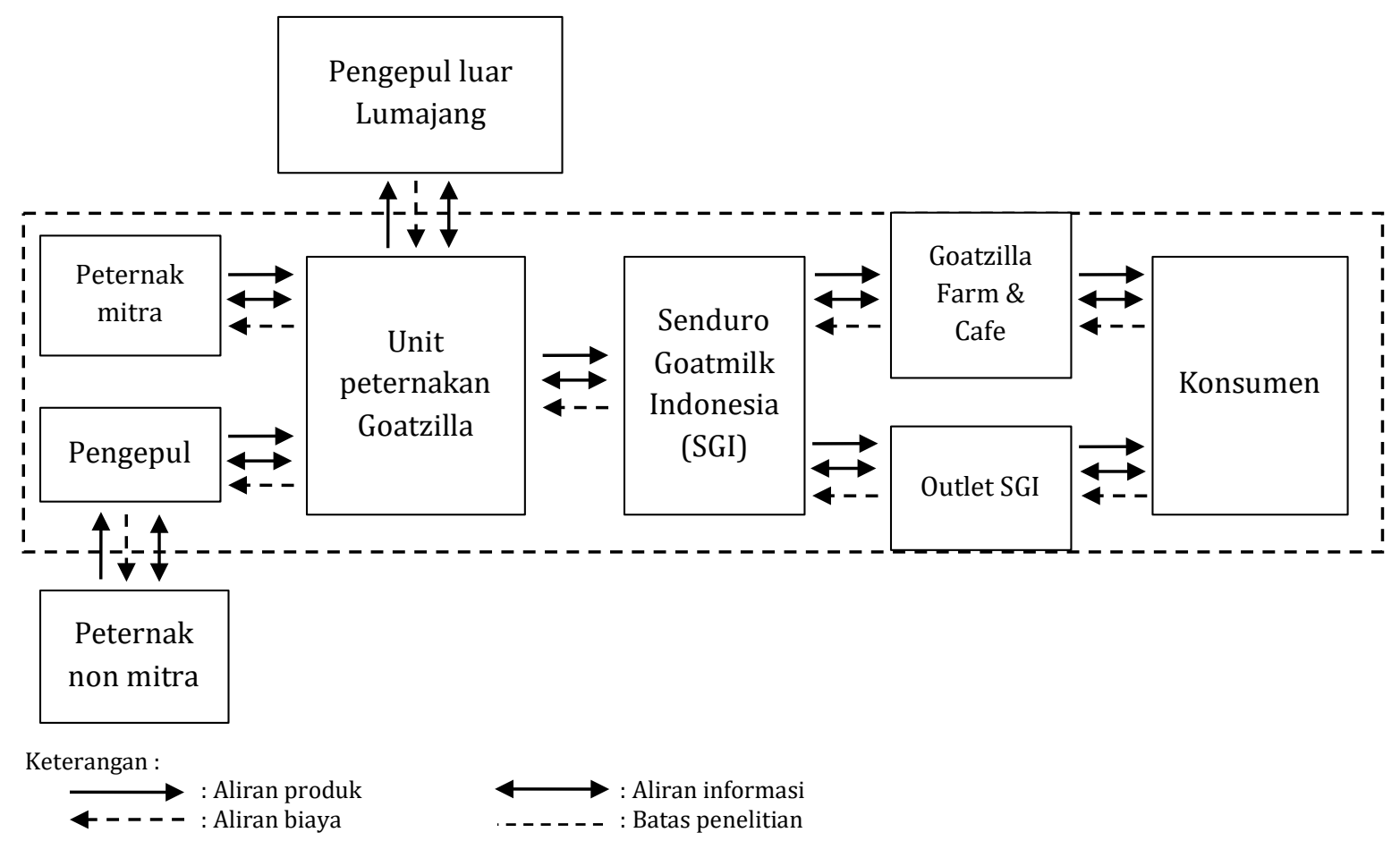

\section{Gambar 1. Pola Aliran Rantai Pasok Susu Pasteurisasi di Goatzilla Farm \& Cafe}

mengalir dari peternak kambing senduro yang merupakan anggota kelompok ternak Etawa Senduro dan merupakan mitra dari Goatzilla Farm \& Cafe serta pedagang pengepul susu kambing segar yang ada di Kecamatan Senduro. Peternak mitra memasok susu kambing segar ke unit peternakan Goatzilla setiap hari dan tidak ada batasan minimum ataupun maksimum dari Goatzilla untuk kuantitas susu yang disetorkan, sehingga kuantitas susu yang diterima oleh Goatzilla tidak pasti. Sementara pedagang pengepul memasok susu kambing ke Goatzilla ketika pasokan susu kambing dari unit peternakan pribadi maupun peternak mitra tidak mencukupi untuk produksi susu pasteurisasi. Susu kambing yang telah terkumpul di unit peternakan Goatzilla selanjutnya disetor ke unit pengolahan, yaitu Senduro Goatmilk Indonesia.

Senduro Goatmilk Indonesia mengolah susu kambing menjadi berbagai produk dengan merek dagang Daimeru (Fresh Dairy from $M t$. Semeru) dan produk utama yang diproduksi oleh Senduro Goatmilk Indonesia adalah susu pasteurisasi. Terdapat tiga variasi rasa susu pasteurisasi, yaitu cokelat, stroberi, dan original, di mana masing-masing rasa tersebut memiliki segmen pasar yang berbeda, yaitu rasa cokelat untuk konsumen umum, stroberi untuk anakanak, dan original untuk dewasa. Produk susu pasteurisasi selanjutnya didistribusikan ke konsumen akhir melalui Goatzilla Farm \& Cafe serta outlet Senduro Goatmilk. Distribusi susu pasteurisasi ke Goatzilla Farm \& Cafe dilakukan setiap setelah produksi dilakukan, sedangkan untuk outlet Senduro Goatmilk Indonesia dilakukan setiap seminggu sekali atau ketika produk di outlet telah menipis.

Aliran biaya merupakan perpindahan uang pembayaran untuk produk dari setiap mata rantai yang terlibat dalam rantai pasok yang mengalir dari hilir (downstream) hingga ke hulu (upstream). Terdapat tujuh aliran biaya yang mengalir dari konsumen hingga ke pemasok susu kambing. Pertama, yaitu aliran biaya yang mengalir dari unit peternakan Goatzilla ke peternak mitra atas pembelian susu kambing. Sistem pembayaran dilakukan setiap 10 hari sekali secara tunai, di mana sistem pembayaran tersebut telah disepakati oleh peternak dan pihak Goatzilla. Harga susu yang dibayarkan oleh Goatzilla ke peternak cenderung stabil, yaitu sebesar Rp 13.000 per liter. Kedua, yaitu aliran biaya yang mengalir dari unit peternakan Goatzilla ke pengepul atas pembelian susu kambing. 
Sistem pembayaran dilakukan sesuai dengan kesepakatan yang dilakukan saat transaksi, yaitu pembayaran secara langsung atau beberapa hari kemudian. Harga susu yang dibayarkan oleh Goatzilla ke pengepul adalah sebesar Rp 13.000 hingga Rp 14.000 per liter. Ketiga, yaitu aliran biaya yang mengalir dari unit pengolahan Senduro Goatmilk Indonesia ke unit peternakan Goatzilla, di mana walaupun keduanya merupakan bagian usaha dari Goatzilla Farm \& Cafe, terdapat sistem pembayaran tersendiri antara unit peternakan Goatzilla dengan unit pengolahan Senduro Goatmilk Indonesia. Pembayaran susu kambing oleh Senduro Goatmilk Indonesia dilakukan secara tunai setelah produk olahan dari susu kambing tersebut laku terjual. Harga susu kambing yang dibayarkan ke unit peternakan adalah sebesar Rp 18.000 per liter.

Keempat, yaitu aliran biaya dari unit penjualan Senduro Farm \& Cafe ke unit pengolahan Senduro Goatmilk Indonesia untuk susu pasteurisasi. Pembayaran dari Senduro Farm \& Cafe dilakukan secara langsung setelah memperoleh pembayaran dari konsumen, yaitu sebesar Rp 10.000 per botol. Kelima, yaitu aliran biaya dari outlet Senduro Goatmilk Indonesia ke unit pengolahan Senduro Goatmilk Indonesia. Pembayaran susu pasteurisasi dari outlet Senduro Goatmilk Indonesia dilakukan seminggu sekali atau setiap pengiriman susu pasteurisasi pada periode selanjutnya. Terakhir, yaitu aliran biaya dari konsumen ke unit penjualan Goatzilla Farm \& Cafe serta outlet Senduro Goatmilk Indonesia yang dilakukan secara langsung dengan harga Rp 10.000 per botol.

Aliran informasi merupakan proses perpindahan informasi dari satu mata rantai ke mata rantai lainnya yang tergabung dalam suatu rantai pasok. Pertukaran informasi yang dilakukan oleh mata rantai yang terlibat dalam rantai pasok susu pasteurisasi diantaranya adalah terkait ketersediaan dan permintaan harga bahan baku berupa susu kambing, harga susu kambing di tingkat peternak dan pengepul, kualitas susu kambing, ketersediaan dan permintaan susu pasteurisasi, serta kritik dan saran dari konsumen terkait produk susu pasteurisasi. Pertukaran informasi yang terjadi antara peternak mitra dengan unit peternakan Goatzilla adalah terkait ketersediaan, harga, dan kualitas susu kambing. Pertukaran informasi yang terjadi antara pedagang pengepul dengan unit peternakan Goatzilla meliputi informasi terkait permintaan, ketersediaan, dan harga susu kambing segar, serta kesepakatan pembayaran. Pertukaran informasi antara unit peternakan Goatzilla dengan unit pengolahan Senduro Goatmilk Indonesia meliputi permintaan dan ketersediaan susu kambing, beserta harganya. Pertukaran informasi antara unit pengolahan Senduro Goatmilk Indonesia dengan unit penjualan Goatzilla Farm \& Cafe dan outlet Senduro Goatmilk Indonesia umumnya meliputi ketersediaan dan pemintaan produk. Pertukaran informasi antara unit penjualan Goatzilla Farm \& Cafe dan outlet Senduro Goatmilk Indonesia dengan konsumen meliputi permintaan dan ketersediaan produk, serta kritikan dan saran dari konsumen. Penyampaian kritik dan saran dari konsumen umumnya dilakukan melalui media sosial seperti instagram, facebook, dan ulasan di google.

\section{NILAI TAMBAH SUSU KAMBING PASTEURISASI DI GOATZILLA FARM \& CAFE}

Menurut Soejono (2011) nilai tambah merupakan penambahan nilai yang tedapat pada suatu produk setelah mengalami pengolahan lebih lanjut yang menghasilkan nilai lebih tinggi daripada sebelum mengalami pengolahan. Analisis nilai tambah dapat menjadi salah satu indikator untuk melihat adanya keterkaitan antara sektor pertanian dengan sektor industri pengolahan yang digambarkan melalui pengolahan bahan yang menyebabkan adanya pertambahan nilai produksi (Yanuasari et al., 2015). Nilai tambah merupakan selisih antara komoditas yang mendapatkan perlakuan pada tahap tertentu dengan nilai yang dikeluarkan selama proses berlangsung. Tujuan nilai tambah adalah untuk mengukur balas jasa yang diterima pelaku bisnis dan kesempatan kerja yang dapat diciptakan oleh sistem komoditas (Sudiyono dalam Rizqiah dan Setiawan, 2014).

Perhitungan nilai tambah dari susu kambing segar hingga menjadi susu pasteurisasi di Goatzilla Farm \& Cafe dianalisis menggunakan metode Hayami. Analisis nilai tambah susu 
pasteurisasi menggunakan satuan per liter bahan baku susu kambing selama satu kali proses produksi. Besarnya nilai tambah susu pasteurisasi di Goatzilla Farm \& Cafe dapat dilihat pada Tabel 1. Berdasarkan perhitungan nilai tambah susu kambing segar menjadi susu pasteurisasi dengan metode Hayami, dapat diketahui bahwa pengolahan 1 liter susu kambing dapat menghasilkan 0,98 liter susu pasteurisasi. Nilai konversi ini menunjukkan adanya penyusutan bahan baku yang disebabkan perlakuan unit pengolahan yang memanaskan susu kambing (proses pasteurisasi) dengan teknik HTST (High Temperature Short Time), yaitu pemanasan pada suhu relatif tinggi dengan waktu relatif singkat pada suhu $72^{\circ} \mathrm{C}$ selama 15 detik. Metode HTST dinilai lebih efektif dibanding metode LTLT (Low Temperature Long Time) karena lebih sedikit menimbulkan kerusakan pada kandungan gizi dan karakteristik organoleptik pada susu (Budiyono, 2009).

Input penggunaan tenaga kerja menggunakan jam/proses produksi. Jumlah tenaga kerja untuk proses pengolahan susu kambing mulai dari sortasi hingga pengemasan adalah sebanyak dua orang dengan total jam kerja sebanyak tiga jam untuk menghasilkan 49 botol susu pasteurisasi, atau dengan rincian 1,47 jam untuk menghasilkan susu pasteurisasi rasa cokelat, 0,98 jam untuk menghasilkan susu pasteurisasi rasa stroberi, dan 0,55 jam untuk menghasilkan susu pasteurisasi rasa original. Hasil koefisien tenaga kerja menunjukkan input tenaga kerja yang dibutuhkan oleh unit pengolahan Senduro Goatmilk Indonesia dalam mengolah 1 liter bahan baku menjadi susu pasteurisasi adalah sebesar 0,24 jam/liter dalam satu kali proses produksi. Upah yang diberikan yaitu Rp 8.166,67 per jam untuk dua orang tenaga kerja, baik untuk produksi susu pasteurisasi rasa cokelat, stroberi, maupun original.

Harga produk susu pasteurisasi di Goatzilla Farm \& Cafe adalah Rp 10.000 per botol dengan ukuran $250 \mathrm{ml}$ atau Rp 40.000 per liter, baik untuk susu pasteurisasi rasa cokelat, stroberi, maupun original. Harga bahan baku berupa susu kambing segar adalah Rp 18.000 per liter. Biaya lain yang diperhitungkan dalam produksi susu pasteurisasi selain biaya bahan baku adalah biaya botol kemasan, label, listrik, gas LPG, dan penyusutan alat, serta perasa makanan dan gula

Tabel 1. Perhitungan Nilai Tambah Susu Kambing Segar Menjadi Susu Pasteurisasi Per-Proses Produksi pada Unit Pengolahan Senduro Goatmilk Indonesia

\begin{tabular}{|c|c|c|c|c|c|c|}
\hline \multirow{2}{*}{ No. } & \multirow{2}{*}{ Variabel } & \multirow{2}{*}{ Satuan } & \multirow{2}{*}{ Formula } & \multicolumn{3}{|c|}{ Nilai } \\
\hline & & & & Cokelat & Stroberi & Original \\
\hline \multicolumn{7}{|c|}{ Output, Input, dan Harga Output } \\
\hline 1 & Output & $\mathrm{L}$ & (1) & 6 & 4 & 2,25 \\
\hline \multirow[t]{2}{*}{2} & Bahan baku (susu & & & & & \\
\hline & kambing segar) & $\mathrm{L}$ & (2) & 6,12 & 4,08 & 2,30 \\
\hline 3 & Tenaga kerja & Jam & (3) & 1,47 & 0,98 & 0,55 \\
\hline 4 & Faktor konversi & & $(4)=(1) /(2)$ & 0,98 & 0,98 & 0,98 \\
\hline \multirow[t]{2}{*}{5} & Koefisien tenaga & & & & & \\
\hline & kerja & jam/L & $(5)=(3) /(2)$ & 0,24 & 0,24 & 0,24 \\
\hline 6 & Harga output & $\mathrm{Rp} / \mathrm{L}$ & (6) & 40000 & 40000 & 40000 \\
\hline 7 & Upah tenaga kerja & $\mathrm{Rp} / \mathrm{jam}$ & (7) & 8166,67 & 8166,67 & 8166,67 \\
\hline \multicolumn{7}{|c|}{ Penerimaan dan Keuntungan/L Susu Pasteurisasi } \\
\hline 8 & Harga bahan baku & $\mathrm{Rp} / \mathrm{L}$ & $(8)$ & 18000 & 18000 & 18000 \\
\hline 9 & Harga input lain & & (9) & 8364,80 & 8394,80 & 7624,80 \\
\hline 10 & Nilai output & $\mathrm{Rp} / \mathrm{L}$ & $(10)=(4) \times(6)$ & 39200 & 39200 & 39200 \\
\hline \multirow[t]{2}{*}{11} & a. Nilai tambah & $\mathrm{Rp} / \mathrm{L}$ & $(11 a)=(10)-(8)-(9)$ & 12835,20 & 12805,20 & 13575,20 \\
\hline & $\begin{array}{l}\text { D. } \\
\text { tambah }\end{array}$ & $\%$ & $(11 b)=(11 a) /(10) \times 100$ & 32,74 & 32,67 & 34,63 \\
\hline \multirow[t]{3}{*}{12} & a. Pendapatan & & & & & \\
\hline & tenaga kerja & $\mathrm{Rp} / \mathrm{L}$ & $(12 a)=(5) \times(7)$ & 1960 & 1960 & 1960 \\
\hline & $\begin{array}{l}\text { b. Pangsa tenaga } \\
\text { kerja }\end{array}$ & $\%$ & $(12 b)=(12 a) /(11 a) \times 100$ & 15,27 & 15,30 & 14,44 \\
\hline \multirow[t]{2}{*}{13} & a. Keuntungan & $\mathrm{Rp} / \mathrm{L}$ & $(13 a)=(11 a)-(12 a)$ & 10875,20 & 10845,20 & 11615,20 \\
\hline & $\begin{array}{l}\text { b. Tingkat } \\
\text { keuntungan }\end{array}$ & $\%$ & $(13 b)=(13 a) /(10) \times 100$ & 27,74 & 27,67 & 29,63 \\
\hline
\end{tabular}


pasir untuk susu pasteurisasi rasa cokelat dan stroberi. Bahan baku susu kambing dan seluruh total biaya input lain merupakan intermediate cost.

Nilai tambah pengolahan susu kambing menjadi susu pasteurisasi rasa cokelat, stroberi, dan original ditentukan dari nilai output berupa susu pasteurisasi dan intermediate cost yang terdiri atas harga bahan baku susu kambing serta total biaya input lain. Nilai tambah merupakan hasil pengurangan antara nilai produk atau nilai output dengan intermediate cost. Nilai output atau nilai susu pasteurisasi merupakan nilai yang diperoleh dari hasil perkalian antara faktor konversi dengan harga jual susu pasteurisasi, di mana nilai susu pasteurisasi dari dari hasil perhitungan adalah Rp 39.200 untuk setiap liter susu pasteurisasi rasa cokelat, stroberi, maupun original.

Berdasarkan Tabel 1 dapat diketahui bahwa nilai tambah susu pasteurisasi rasa cokelat adalah sebesar Rp 12.835,20 per liter bahan baku. Hal tersebut menunjukkan bahwa pertambahan nilai yang diperoleh dari pengolahan setiap liter bahan baku susu kambing menjadi susu pasteurisasi rasa cokelat adalah sebesar Rp $12.835,20$ per liter atau $32,74 \%$ dari nilai susu pasteurisasi rasa cokelat. Nilai tambah susu pasteurisasi rasa stroberi adalah $\mathrm{Rp} 12.805,20$ per liter bahan baku. Hal tersebut menunjukkan bahwa pertambahan nilai yang diperoleh dari pengolahan setiap liter bahan baku susu kambing menjadi susu pasteurisasi rasa stroberi adalah sebesar Rp 12.805,20 per liter atau 32,67\% dari nilai susu pasteurisasi rasa stroberi. Nilai tambah susu pasteurisasi rasa original adalah $\mathrm{Rp}$ 13.575,20 per liter bahan baku. Hal tersebut menunjukkan bahwa pertambahan nilai yang diperoleh dari pengolahan setiap liter bahan baku susu kambing menjadi susu pasteurisasi rasa original adalah sebesar Rp 13.575,20 per liter atau $34,63 \%$ dari nilai susu pasteurisasi rasa orginal. Rasio nilai tambah susu pasteurisasi rasa cokelat sebesar $32,74 \%$, susu pasteurisasi rasa stroberi sebesar 32,67\%, dan susu pasteurisasi rasa original sebesar $34,63 \%$ menunjukkan bahwa pertambahan nilai yang diperoleh dari pengolahan susu kambing menjadi susu pasteurisasi adalah sedang. Hal ini sesuai dengan teori dari Hubeis (1997) yang menyebutkan bahwa jika besar rasio nilai tambah dari suatu produk nilainya 15\%-40\% maka nilai tambahnya sedang.

Besarnya nilai tambah susu pasteurisasi dipengaruhi oleh harga jual susu pasteurisasi, harga bahan baku susu kambing, serta total biaya input lainnya, di mana besar nilai tambah tersebut belum sepenuhnya menjadi keuntungan unit pengolahan Senduro Goatmilk Indonesia atau Goatzilla Farm \& Cafe karena masih mengandung biaya tenaga kerja. Pendapatan tenaga kerja dari setiap liter susu kambing yang diolah menjadi susu pasteurisasi adalah sebesar Rp 1.960 per liter bahan baku dengan pangsa tenaga kerja sebesar 15,27\% dari nilai tambah susu pasteurisasi rasa cokelat, $15,30 \%$ dari nilai tambah susu pasteurisasi rasa stroberi, dan $14,44 \%$ dari nilai tambah susu pasteurisasi rasa original.

Keuntungan yang diperoleh unit pengolahan Senduro Goatmilk Indonesia dari setiap liter bahan baku susu kambing adalah sebesar Rp $10.875,20$ dengan rasio keuntungan 27,74\% untuk susu pasteurisasi rasa cokelat, $\mathrm{Rp}$ $10.845,20$ dengan rasio keuntungan 27,67\% untuk susu pasteurisasi rasa stroberi, dan Rp $11.615,20$ dengan rasio keuntungan 29,63\% untuk susu pasteurisasi rasa original. Soeharjo dalam Hasanah et al. (2015) menyebutkan bahwa apabila tingkat keuntungan yang diperoleh (\%) tinggi, maka agroindustri lebih berperan dalam meningkatkan pertumbuhan ekonomi, sedangkan apabila rasio imbalan tenaga kerja terhadap nilai tambah (\%) tinggi, maka agroindustri lebih berperan dalam memberikan pendapatan bagi pekerjanya sehingga berperan dalam mengatasi masalah pengangguran melalui pemerataan kesempatan kerja.

Keuntungan yang diperoleh tersebut berbanding lurus dengan nilai tambah produk, di mana susu pasteurisasi rasa original memberikan nilai tambah dan keuntungan lebih tinggi dibanding susu pasteurisasi rasa cokelat dan stroberi. Hal tersebut dikarenakan susu pasteurisasi rasa original tidak membutuhkan input tambahan berupa perasa makanan dan gula pasir, sementara harga jualnya sama dengan susu pasteurisasi rasa cokelat dan stroberi yang 
menggunakan input tambahan tersebut. Susu pasteurisasi rasa cokelat memberikan nilai tambah dan keuntungan lebih tinggi dibanding susu pasteurisasi rasa stroberi dikarenakan harga perasa makanan cokelat lebih murah dibanding perasa makanan stroberi.

\section{STRATEGI PENGEMBANGAN SUSU KAMBING PASTEURISASI DI GOATZILLA FARM \& CAFE}

Menurut Sianipar dan Entang dalam Fatih (2010), teknik force field analysis (FFA) menyatakan bahwa suatu sistem berada pada keadaan seimbang karena adanya faktor-faktor yang berperan dalam sistem tersebut, di mana faktor tersebut terdiri atas faktor pendorong dan penghambat. Berdasarkan hasil wawancara yang dilakukan secara mendalam dengan pengelola Goatzilla Farm \& Cafe serta para expert (pakar atau ahli), terdapat lima faktor pendorong dan lima faktor penghambat dalam pengembangan susu pasteurisasi di Goatzilla Farm \& Cafe. Faktor pendorong dalam pengembangan susu pasteurisasi di Goatzilla Farm \& Cafe adalah sebagai berikut:

1. Susu kambing memiliki beragam manfaat

Terdapat beragam manfaat susu kambing yang masih jarang diketahui oleh masyarakat. Hal ini dikarenakan masyarakat umumnya mengkonsumsi susu sapi, selain itu susu kambing masih jarang beredar secara umum di pasaran. Beberapa manfaat susu kambing diantaranya yaitu menjaga kesehatan tulang, mengobati diabetes, mengobati gangguan pernafasan seperti asma dan TBC, mencegah penyakit saraf, meningkatkan kekebalan tubuh, serta membantu meningkatkan kecerdasan. Selain memiliki beragam manfaat, susu kambing lebih mudah diserap dan dicerna oleh tubuh, serta memiliki risiko alergi lebih rendah apabila dibandingkan dengan susu sapi.

2. Lokasi produksi yang strategis

Produksi susu pasteurisasi dilakukan di Goatzilla Farm \& Cafe yang berlokasi di Jalan Raya B29 Nomor 29 Desa Kandangtepus Kecamatan Senduro Kabupaten Lumajang, di mana lokasi tersebut berada di jalan utama menuju tempat wisata B29. Hal tersebut tentunya dapat berdampak positif terhadap pemasaran produk karena lokasi tersebut banyak dilalui oleh wisatawan. Selain itu, Desa Kandangtepus merupakan sentral peternakan kambing senduro, sehingga akses untuk memperoleh bahan baku lebih mudah dan ditunjang dengan kondisi jalan yang cukup baik.

3. Dukungan dari pemerintah setempat Beberapa bentuk perhatian atau dukungan pemerintah terhadap pengembangan susu pasteurisasi di Goatzilla Farm \& Cafe adalah melalui informasi atau akses untuk mengikuti pameran di luar kota, pelatihan, studi banding, serta promosi kepada tamu dinas atau pemerintah dengan mengajak para tamu berkunjung ke Goatzilla Farm \& Cafe. Pemerintah melalui Dinas Pertanian juga

Tabel 2. Evaluasi Faktor Pendorong pada Pengembangan Susu Pasteurisasi di Goatzilla Farm \& Cafe

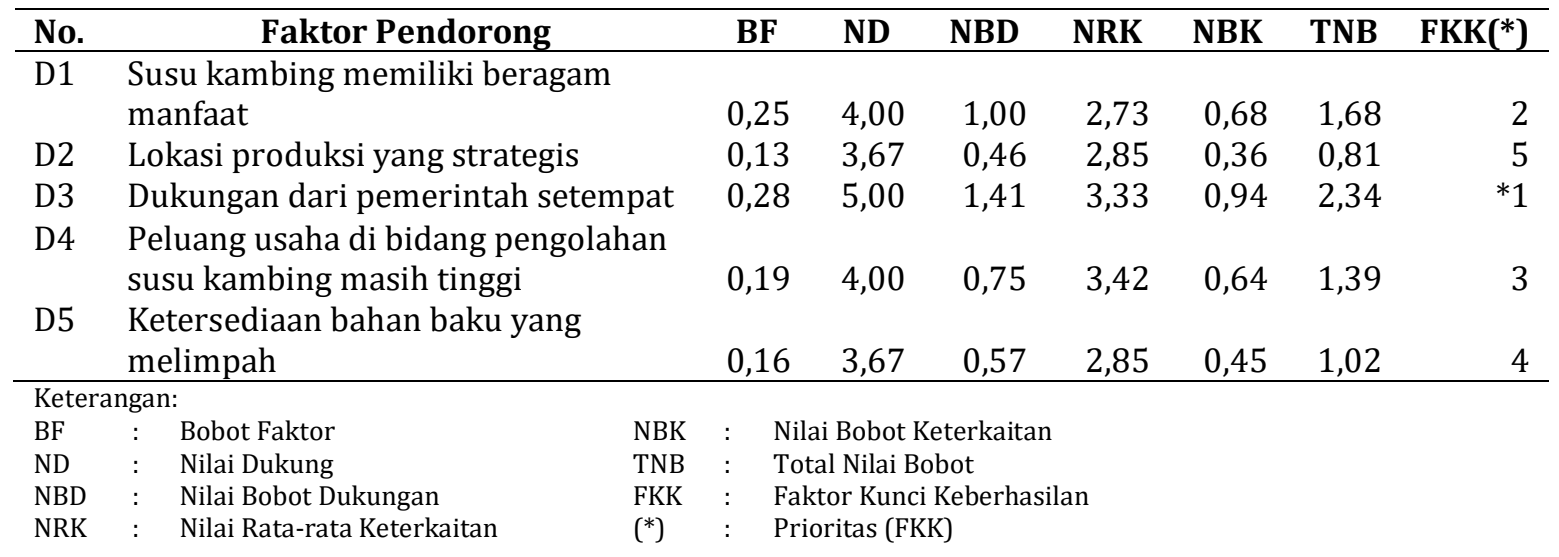

Sumber: Data primer diolah (2018) 
sering menggelar Aksi Gerakan Minum Susu Kambing Senduro (Si-Gamis) sejak tahun 2017, di mana susu kambing yang dikonsumsi merupakan produk susu pasteurisasi dari Goatzilla Farm \& Cafe. Kegiatan tersebut tentunya membantu pelaku usaha Goatzilla Farm \& Cafe dalam mengenalkan produknya ke masyarakat.

4. Peluang usaha di bidang pengolahan susu kambing masih tinggi

Susu kambing memiliki beragam manfaat dan keunggulan dibanding susu sapi. Akan tetapi, industri atau usaha pengolahan susu kambing masih jauh lebih sedikit dibanding susu sapi. Hal ini dapat menjadi salah satu peluang usaha di bidang pengolahan susu kambing. Selain itu, saat ini tingkat kesadaran masyarakat untuk hidup sehat semakin tinggi. Hal tersebut dapat menjadi salah satu pemicu yang mendorong masyarakat untuk mengkonsumsi susu kambing tidak hanya sebagai alternatif pengobatan, tetapi juga untuk konsumsi sehari-hari

5. Ketersediaan bahan baku yang melimpah Berdasarkan data dari Dinas Peternakan dan Kesehatan Hewan Kabupaten Lumajang, pada tahun 2017 populasi kambing di Kecamatan Senduro adalah 24.580 ekor atau sekitar 24\% dari total populasi kambing di Kabupaten Lumajang yang sebesar 103.658 ekor. Mayoritas jenis kambing yang ada di Kecamatan Senduro adalah kambing senduro. Tingginya populasi kambing senduro tentunya berban- ding lurus dengan jumlah susu kambing, sehingga dapat dikatakan ketersediaan susu kambing di Kecamatan Senduro cukup melimpah. Hal ini juga dapat dilihat melalui banyaknya peternak non mitra yang mengirim susu kambing segar ke luar daerah Lumajang, seperti Surabaya, Yogyakarta, Madura, dan Bali. Apabila susu pasteurisasi di Goatzilla Farm \& Cafe semakin berkembang dan kapasitas produksinya semakin meningkat, tentunya unit pengolahan akan membutuhkan lebih banyak pasokan susu kambing segar, dan hal tersebut tidak akan menjadi masalah karena ketersediaan bahan baku yang melimpah, khususnya di sekitar lokasi produksi. Ketersediaan bahan baku yang melimpah juga dapat berdampak positif terhadap biaya produksi karena pelaku usaha tidak perlu mengeluarkan lebih banyak biaya untuk transportasi.

Faktor penghambat dalam pengembangan susu pasteurisasi di Goatzilla Farm \& Cafe adalah sebagai berikut:

1. Keterbatasan pasar karena perizinan BPOM Produk olahan susu pasteurisasi di Goatzilla Farm \& Cafe hingga saat ini masih belum memiliki izin edar BPOM. Hal tersebut tentunya berdampak terhadap pemasaran produk karena pelaku usaha ataupun distributor tidak dapat memasarkan produk secara bebas. Selain itu, tidak adanya izin edar dari BPOM dapat berpengaruh terhadap kepercayaan konsumen terhadap produk, misalnya dari

Tabel 3. Evaluasi Faktor Penghambat pada Pengembangan Susu Pasteurisasi di Goatzilla Farm \& Cafe

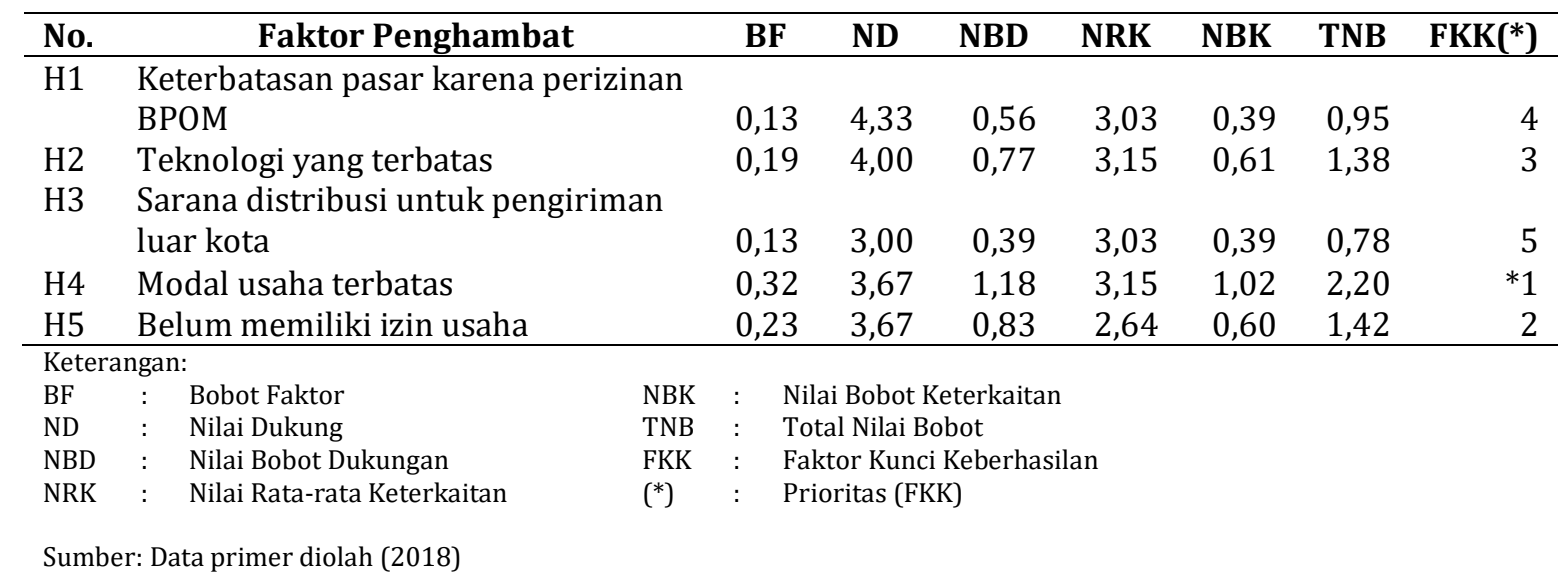


segi kandungan, kebersihan, dan lain-lain.

2. Teknologi yang terbatas

Pengolahan susu pasteurisasi di Goatzilla Farm \& Cafe masih merupakan industri rumah tangga dan menggunakan peralatan rumah tangga untuk proses produksinya. Penggunaan peralatan atau teknologi yang terbatas, seperti mesin pasteurisasi dan homogenizer tentunya dapat berpengaruh terhadap produksi ataupun kualitas produk. Salah satu dampak dari terbatasnya penggunaan teknologi pada pengolahan susu pasteurisasi di Goatzilla Farm \& Cafe adalah adanya lemak susu yang menggumpal apabila susu tidak beku dalam waktu cepat. Penggumpalan lemak susu tersebut sebenarnya tidak berdampak negatif terhadap kandungan nutrisi pada susu dan masih aman dikonsumsi. Akan tetapi, hal tersebut dapat menurunkan minat konsumen terhadap produk karena konsumen tidak dapat langsung mengkonsumsi susu pasteurisasi dan harus menunggu hingga produk mencair.

3. Sarana distribusi untuk pengiriman luar kota Pengiriman susu pasteurisasi untuk wilayah Lumajang dilakukan langsung oleh pihak Goatzilla Farm \& Cafe, sedangkan untuk luar daerah Lumajang menggunakan jasa ekspedisi. Pengiriman susu pasteurisasi dengan jasa ekspedisi dilakukan dengan menggunakan box sterofoam untuk meminimalisir suhu udara yang meningkat, mencegah produk agar tidak terkontaminasi bau tajam, serta agar kemasan tidak rusak. Akan tetapi, pengiriman dengan menggunakan jasa ekspedisi tetap memiliki risiko tersendiri walaupun pihak Goatzilla Farm \& Cafe telah mengemas produk sedemikian rupa untuk menjaga kualitas. Hal ini dikarenakan terkadang pihak ekspedisi mengalami overload atau hambatan lain sehingga produk tidak dapat sampai ke konsumen tepat waktu dan juga berdampak terhadap kualitas produk yang menurun atau rusak karena terlalu lama berada pada suhu ruang.

4. Modal usaha terbatas

Permodalan secara finansial merupakan salah satu aspek yang cukup berpengaruh terhadap perkembangan susu pasteurisasi di Goatzilla
Farm \& Cafe. Modal usaha yang terbatas tentunya berpengaruh terhadap investasi, seperti pembangunan atau renovasi tempat usaha hingga memiliki standar yang sesuai untuk memenuhi persyaratan perizinan BPOM, serta kepemilikan alat atau teknologi untuk kegiatan produksi. Keterbatasan modal untuk investasi tersebut dapat berdampak terhadap kapasitas produksi, kualitas produk, serta pemasaran produk.

5. Belum memiliki izin usaha

Perizinan usaha merupakan aspek yang sangat penting dalam suatu usaha karena berkaitan dengan legalitas usaha tersebut sehingga pelaku usaha juga akan memperoleh perlindungan hukum dari pihak berwenang. Selain itu, dengan adanya izin usaha, pelaku usaha juga akan memproleh kemudahan akses dana ke perbankan ataupun non perbankan. Perizinan usaha ini juga dibutuhkan untuk memproleh izin edar dari BPOM. Oleh karena itu, tanpa adanya izin usaha dari pihak yang berwenang, Goatzilla Farm \& Cafe tidak dapat memperoleh izin edar dari BPOM.

Langkah selanjutnya setelah identifikasi terhadap faktor pendorong dan penghambat dalam pengembangan susu pasteurisasi di Goatzilla Farm \& Cafe adalah memberikan penilaian terhadap masing-masing faktor pendorong dan penghambat. Berdasarkan evaluasi faktor pendorong pada pengembangan susu pasteurisasi di Goatzilla Farm \& Cafe dapat diketahui bahwa Faktor Kunci Keberhasilan (FKK) faktor pendorong pada pengembangan susu pasteurisasi di Goatzilla Farm \& Cafe yang memiliki nilai tertinggi adalah dukungan dari pemerintah setempat (D3) dengan nilai 2,34. Dukungan dari pemerintah sangat membantu dalam proses pengembangan susu pasteurisasi di Goatzilla Farm \& Cafe, khususnya dalam pendampingan dan promosi produk. Pendampingan yang dilakukan pemerintah dalam bentuk pelatihan dan studi banding tentunya dapat meningkatkan pengetahuan dan skill pelaku usaha, sementara promosi produk susu pasteurisasi membantu pengenalan produk ke masyarakat dan meningkatkan pangsa pasar. Dukungan dari pemerintah ini diharapkan dapat semakin meningkatkan pengembangan susu 
pasteurisasi mulai dari hulu hingga hilir, yaitu mulai dari susu pasteurisasi masih dalam bentuk bahan baku berupa susu kambing mentah hingga produk sampai ke tangan konsumen. Selain faktor pendorong, terdapat faktor penghambat yang menghambat berkembangnya susu pasteurisasi di Goatzilla Farm \& Cafe.

Berdasarkan evaluasi faktor penghambat pada pengembangan susu pasteurisasi di Goatzilla Farm \& Cafe dapat diketahui bahwa berdasarkan TNB, faktor penghambat tertinggi pada pengembangan susu pasteurisasi di Goatzilla Fam \& Cafe adalah modal usaha yang terbatas (H4) dengan TNB terbesar 2,20. Modal usaha secara finansial dapat menjadi penentu cepat lambatnya pengembangan suatu usaha ataupun produk. Hal ini dikarenakan modal dibutuhkan untuk investasi berupa alat atau teknologi yang menunjang proses produksi dan pembangunan tempat usaha, riset pasar, peningkatan kapasitas produksi, dan lain-lain. Adapun medan kekuatan dari faktor pendorong dan penghambat pada pengembangan susu pasteurisasi di Goatzilla Fam \& Cafe dapat dilihat pada Gambar 2.

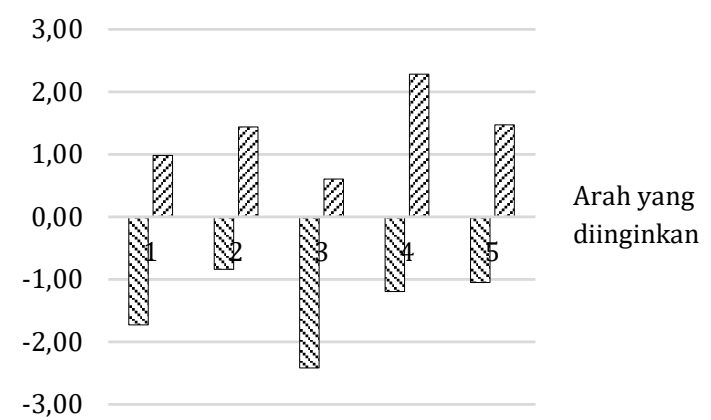

冈 Faktor Pendorong $\&$ Faktor Penghambat

\section{Gambar 2. Medan Kekuatan pada Pengembangan Susu Pasteurisasi di Goatzilla Farm \& Cafe}

Berdasarkan Gambar 2 dapat diketahui bahwa faktor pendorong tertinggi adalah D3 yaitu dukungan dari pemerintah setempat, sedangkan faktor penghambat tertinggi adalah $\mathrm{H} 4$ yaitu modal usaha yang terbatas. Jumlah TNB faktor pendorong adalah sebesar 7,25, sedangkan jumlah TNB faktor penghambat sebesar 6,74. Nilai tersebut menunjukkan bahwa jumlah TNB faktor pendorong lebih tinggi dibanding jumlah TNB faktor penghambat, sehingga dapat dikatakan bahwa susu pasteurisasi di Goatzilla Farm \& Cafe memiliki potensi untuk semakin dikembangkan.

Langkah selanjutnya setelah mengetahui arah medan kekuatan pada pengembangan susu pasteurisasi di Goatzilla Farm \& Cafe adalah merumuskan rekomendasi kebijakan yang sesuai dengan Faktor Kunci Keberhasilan (FKK) pada faktor pendorong dan penghambat. Rekomendasi kebijakan yang dirumuskan diharapkan dapat menjadi salah satu upaya yang tepat agar tujuan yang telah ditetapkan, yaitu pengembangan susu pasteurisasi, dapat tercapai. Berdasarkan hasil analisis medan kekuatan, strategi fokus yang direkomendasikan berdasarkan FKK pendorong dan penghambat, yaitu mengatasi masalah permodalan yang terbatas dan mengoptimalkan dukungan dari pemerintah, adalah dengan membentuk badan usaha koperasi yang bergerak dalam bidang agribisnis susu kambing senduro. Goatzilla Farm \& Cafe beserta peternak kambing senduro, khususnya peternak mitra, dapat memelopori pembentukan koperasi usaha susu kambing senduro dengan bantuan dan pendampingan dari pemerintah. Pembentukan koperasi utamanya diharapkan dapat mengatasi masalah permodalan yang terbatas dan dukungan pemerintah terhadap pengembangan susu kambing pasteurisasi semakin optimal melalui pengembangan koperasi. Permodalan dapat dihimpun dari anggota koperasi, diantaranya melalui simpanan pokok, simpanan wajib, dana cadangan, serta hibah, dan selanjutnya anggota memperoleh balas jasa melalui pembagian sisa hasil usaha (SHU).

Keberadaan koperasi yang bergerak dalam agribisnis susu kambing senduro tidak hanya berdampak positif terhadap pelaku usaha, tetapi juga terhadap peternak kambing senduro. Koperasi dapat menjadi wadah bagi peternak kambing senduro untuk meningkatkan kesejahteraan ekonomi dan sosialnya. Peternak dapat memperoleh kepastian pasar serta memperoleh harga jual lebih baik karena pemasaran susu tidak melalui tengkulak.

Menurut UU RI Nomor 25 Tahun 1992, koperasi merupakan badan usaha yang beranggotakan orang-seorang atau badan hukum koperasi dengan melandaskan kegiatannya berdasarkan prinsip koperasi sekaligus sebagai 
gerakan ekonomi rakyat yang berdasar atas asas kekeluargaan. Prinsip koperasi adalah (1) keanggotaan bersifat sukarela dan terbuka; (2) pengelolaan dilaksanakan secara demokratis; (3) pembagian sisa hasil usaha dilakukan secara adil sebanding dengan besarnya jasa usaha masingmasing anggota; (4) pemberian balas jasa yang terbatas terhadap modal; dan (5) kemandirian, sementara dalam mengembangkan koperasi, maka dilaksanakan pula pendidikan perkoperasian dan kerja sama antar koperasi. Menurut Damayanti (2016), peran pemerintah daerah dalam pengembangan koperasi dapat meliputi:

1. Bimbingan berupa penyuluhan, pendidikan, ataupun melakukan riset bagi perkembangan koperasi, serta bantuan konsultasi terhadap permasalahan koperasi;

2. Melakukan pengawasan, termasuk memberikan perlindungan terhadap koperasi berupa penetapan bidang kegiatan ekonomi yang telah berhasil diusahakan oleh koperasi untuk tidak diusahakan oleh badan usaha lainnya;

3. Memberikan fasilitas berupa kemudahan akses permodalan, serta pengembangan jaringan usaha dan kerja sama.

Susu pasteurisasi di Goatzilla Farm \& Cafe dapat berkembang dengan baik apabila faktor pendorong yang ada dapat dioptimalkan dan faktor penghambat yang muncul dapat dihilangkan atau diminimalisir. Berkembangnya susu pasteurisasi di Goatzilla Farm \& Cafe tentunya dapat berdampak positif terhadap pelaku usaha maupun peternak kambing senduro. Oleh karena itu, pengembangan susu pasteurisasi di

Goatzilla Farm \& Cafe perlu memperoleh perhatian khusus karena dapat berdampak positif terhadap agribisnis susu kambing senduro di Kecamatan Senduro Kabupaten Lumajang.

\section{SIMPULAN DAN SARAN}

\section{SIMPULAN}

1. Aliran produk mengalir dari peternak mitra dan pengepul hingga ke konsumen, sedangkan aliran biaya mengalir dari konsumen hingga ke peternak mitra dan pengepul, Aliran informasi terjadi pada setiap mata rantai secara timbal balik atau dua arah berupa harga, kualitas, ketersediaan, dan penawaran susu kambing segar, ketersediaan dan permintaan susu pasteurisasi, serta kritik dan saran terkait produk susu pasteurisasi di Goatzilla Farm \& Cafe.

2. Nilai tambah susu kambing pasteurisasi di Goatzilla Farm \& Cafe bernilai positif dan tergolong sedang, di mana nilai tambah yang diberikan susu pasteurisasi rasa cokelat adalah sebesar Rp 12.835,20/liter bahan baku dengan rasio nilai tambah sebesar 32,74\%; nilai tambah susu pasteurisasi rasa stroberi adalah Rp 12.805,20/liter bahan baku dengan rasio nilai tambah sebesar 32,67\%; dan nilai tambah susu pasteurisasi rasa original adalah Rp 13.575,20/liter bahan baku dengan rasio nilai tambah sebesar $34,63 \%$.

3. Strategi pengembangan berdasarkan hasil FKK faktor pendorong dan penghambat adalah adalah membentuk badan usaha koperasi yang beranggotakan pelaku usaha serta peternak kambing senduro, sehingga masalah permodalan yang terbatas dapat teratasi melalui himpunan modal koperasi dan pemerintah dapat mengoptimalkan dukungannya melalui bimbingan atau pembinaan, pengawasan, serta fasilitas untuk pengembangan koperasi.

\section{SARAN}

1. Peternak lebih memperhatikan informasi atau saran yang diberikan oleh Goatzilla Farm \& Cafe terkait peningkatan kualitas susu kambing segar.

2. Goatzilla Farm \& Cafe dapat bekerja sama dengan lembaga penelitian atau stakeholder terkait pengolahan pangan seperti LIPI, perguruan tinggi, atau lembaga swasta untuk peningkatan kualitas produk.

3. Perlu adanya peningkatan sarana dan prasarana untuk menunjang pengembangan susu pasteurisasi beserta unit usaha Goatzilla Farm \& Cafe lainnya.

4. Goatzilla Farm \& Cafe serta pemerintah atau dinas setempat dapat mempertimbangkan rekomendasi strategi pengembangan yang dirumuskan untuk pengembangan susu kambing pasteurisasi, yaitu membentuk badan usaha koperasi yang bergerak dalam agribisnis susu kambing senduro serta melakukan persiapan terkait pembentukan koperasi. 


\section{DAFTAR PUSTAKA}

Azhim, F., Salengke, dan Zainal. 2014. Strategi Pengembangan Industri Pengolahan Susu Sapi di Kabupaten Sinjai, Sulawesi Selatan. Sains \& Teknologi, 14(2): 162-171.

Budiyono, Haris. 2009. Analisis daya Simpan Produk Susu Pasteurisasi Berdasarkan Kualitas Bahan Baku Mutu Susu. Paradigma, 10(2): 198-211.

Damayanti, Dina. 2016. Peran Pemerintah Daerah terhadap Perkembangan Koperasi di Kabupaten Kendal. Majalah Ilmiah Inspiratif, 2(2): 57-79.

Fatih, Cholid. 2010. Strategi Pengembangan Agroindustri Perikanan Laut di Kabupaten Tuban. JSEP, 4(3): 77-88.

Furqon, Chairul. 2014. Analisis Manajemen dan Kinerja Rantai Pasokan Agribisnis Buah Stroberi di Kabupaten Bandung. Image, 3(2): 109-126.

Hanafie, R., Soetriono, dan Alfiana. 2016. Strategi Pengembangan Industri Pangan Berbahan Dasar Olahan Ketela Pohon. Seminar Nasional Pembangunan Pertanian 2016: 516-522.

Hasanah, U., Mayshuri, dan Djuwari. 2015. Analisis Nilai Tambah Agroindustri Sale Pisang di Kabupaten Kebumen. Ilmu Pertanian, 18(3): 141-149.

Hariyati, Yuli. 2014. Pengembangan Produk Olahan di Desa Sidomulyo Kecamatan Silo Kabupaten Jember. Agriekonomika, 3(1): 8191.

Hayami, Y., T. Kawagoe., Y. Morooka, dan M. Siregar. 1987. Agricultural and Processing in Upland Java A Perspective From A Sunda Village. Bogor: CGPRT Centre.

Hubeis, Musa. 1997. Menuju Industri Kecil Profesional di Era Globalisasi Melalui Pemberdayaan Manajemen Industri. Orasi Ilmiah Guru Besar Tetap Ilmu Manajemen Industri, Fakultas Teknologi Industri, Institut Pertanian Bogor.

Isnia, M., Y. Hariyati, dan A. Kusmiati. 2017. Analisis Manajemen Rantai Pasok Susu Sapi
Perah pada Koperasi Peternak Galur Murni di Kecamatan Sumberbaru Kabupaten Jember. JSEP, 10(1): 65-77.

Liputra, D. T., I. D. Anna, dan W. Kartika. 2015. Pemetaan Entitas dan Aliran pada Jaringan Sistem Rantai Pasok Produk Susu (Studi Kasus di PT. Frisian Flag Indonesia, Jakarta). Integra, 5(1): 1-15.

Nazir, Moh. 1999. Metode Penelitian. Jakarta: Ghalia Indonesia.

Pamungkas, F. A., A. Batubara, M. Doloksaribu, dan E. Sihite. 2009. Petunjuk Teknis: Potensi Beberapa Plasma Nutfah Kambing Lokal Indonesia. Galang Deli Serdang: Pusat Penelitian dan Pengembangan Peternakan.

Pemerintah Indonesia. 1992. Undang-Undang Republik Indonesia Nomor 25 Tahun 1992 tentang Perkoperasian. Lembaran Negara Republik Indonesia Tahun 1992 No. 116. Jakarta: Sekretariat Negara.

Putri, Nataliya Sukmawati. 2015. Analisis Risiko Rantai Pasok Susu Pasteurisasi dengan Fuzzy Failure Mode and effect Analysis [Skripsi]. Bogor: Fakultas Teknologi Pertanian Institut Pertanian Bogor.

Rizqiah, Fatih dan Alim Setiawan. 2014. Analisis Nilai Tambah dan Penentuan Metrik Pengukuran Kinerja Rantai Pasok Pepaya Calina (Studi Kasus di PT. Sewu Segar Nusantara). Manajemen dan Organisasi, $\mathrm{V}(1)$ : 72-89.

Ruauw, E., Th. M. Katiandgho, dan P. A. P. Suwardi. 2012. Analisis Keuntungan dan Nilai Tambah Agroindustri Manisan Pala UD. Putri di Kota Bandung. ASE, 8(1): 31-44.

Salsabila, S. M., R.Wibowo, dan T.Agustina. 2014.Analisis Manajemen Rantai Pasok (Supply Chain Management) Padi Pascapanen di Pabrik Beras Sukoreno Makmur Kecamatan Kalisat. Berkala Ilmiah Pertanian, 1(1): xx-xx.

Saparinto, Cahyo. 2011. 79 Bisnis Pertanian Menguntungkan. Jakarta: Penebar Swadaya.

Sianipar, J.P.G. dan Entang, H.M.. 2003. TeknikTeknik Analisis Manajemen, Bahan Ajar Diklatpim Tingkat III. Jakarta: Lembaga Administrasi Negara - Republik Indonesia. 
Siswanto. 2014. Kambing Senduo: Ternak Unggulan Kabupaten Lumajang. [serial online]

https://lumajangkab.go.id/ternak_potensi.p hp diakses 25 Maret 2017.

Soejono, Djoko. 2011. Strategi Pengembangan Agribisnis dan Agroindustri Sub Sektor Tanaman Pangan di Kabupaten Situbondo. JSEP, 5(3): 54-60.

Sumodiningrat, Gunawan. 2007. Pemberdayaan Sosial. Jakarta: PT. Kompas Media Nusantara.

Utami, Suci Nur. 2016. Pengembangan Agribisnis Kambing Peranakan Ettawa (PE) di Kecamatan Turi Sleman Yogyakata. Agronomika, 11(1): 20-29.

Wanniatie,V. dan Z. Hanum. 2015. Kualitas Susu Pasteurisasi Komersil. Agripet, 15(2): 92-97.

Yanuasari, K. I. R., R. Hartadi, dan S. Raharto. 2015. Analisis Pendapatan dan Nilai Tambah serta Strategi Pengembangan Agroindustri Kacang Oven pada CV. Tds Mitra Garuda di Kabupaten Jember. Agritrop, 13(2): 126136. 